\title{
KAJIAN MACAM PUPUK KANDANG TERHADAP PERTUMBUHAN DAN HASIL TIGA VARIETAS KEDELAI
}

\author{
Haris Asrori ${ }^{1 *}$, Siswadi $^{1}$, and Sumarmi ${ }^{1}$ \\ ${ }^{1}$ Faculty of Agriculture, Slamet Riyadi University \\ hkhenzou@gmail.com
}

\begin{abstract}
Research on "study of types of manure on the growth and yield of three soybean varieties (Glycine max L. Merr)" has been implemented from 29 September 2018 to 3 January 2019 in Hargosari Village, Sine Sub-district, Ngawi District. The purpose of this research was to determine the influence types of manure on the growth and yield of three soybean varieties. Size of polybag $15 \times 30 \mathrm{~cm}$ and $4 \mathrm{~kg}$ land. The methode of this research was experimental designed by completely randomized design (CRD). The treatments composed of two factors with the number of combinations 12 treatments and each treatment combinations 3 replications. Data where analyzed by analysis of variance and continued with Duncan Multiple Range Test (DMRT). The result showed that treatment varieties or manure no significantly different $(P>0.05)$ on crop height, leaves number, flowering age, number of pods, number of seeds. But it happened interaction between varieties and manure in the parameters of the number of seeds. The best treatment on this reseach that planting Anjasmoro varieties soybeans, because have an average crop height 42,83 cm, leaves number 25,04 sheet, flowering age 43,62 days, number of pods 13,00 items, number of seeds 20,16 items, weight of 100 soybean seeds 12,78 g. The best use of manure by using goat manure $400 \mathrm{~g}$ each polybag, because it can produce plant with an average height 48,11 cm, leaves number 26,22 sheet, flowering age 43,16 days, number of pods 13,89 items, number of seeds 17,66 items, weight of 100 soybean seeds $12,56 \mathrm{~g}$.
\end{abstract}

Keywords : Soybean, varieties, manure

\begin{abstract}
ABSTRAK
Penelitian tentang "Kajian Macam Pupuk Kandang Terhadap Pertumbuhan dan Hasil Tiga Varietas Kedelai (Glycine max L.Merr)" telah dilaksanakan mulai tanggal 29 September 2018 sampai 3 Januari 2019 di Desa Hargosari, Kecamatan Sine, Kabupaten Ngawi. Penelitian ini bertujuan untuk mengetahui pengaruh macam pupuk kandang sapi, ayam dan kambing terhadap pertumbuhan dan hasil tiga varietas kedelai yaitu Wilis, Anjasmoro, dan Grobogan. Polybag yang digunakan berukuran $15 \times 30 \mathrm{~cm}$ dan tanah masing-masing polybag $4 \mathrm{~kg}$. Penelitian ini menggunakan metode Rancangan Acak Lengkap (RAL). Perlakuan terdiri dari dua faktor dengan jumlah kombinasi 12 perlakuan dan masing-masing kombinasi perlakuan diulang sebanyak tiga kali. Data dianalisis dengan menggunakan analisis ragam, dan dilanjutkan dengan uji Duncan. Hasil penelitian menunjukkan bahwa perlakuan varietas maupun pupuk kandang tidak berpengaruh nyata $(\mathrm{P}>0,05)$ terhadap tinggi tanaman, jumlah daun, umur berbunga, jumlah polong dan jumlah biji. Namun terjadi interaksi antara varietas dan pupuk kandang dalam parameter jumlah biji. Perlakuan terbaik pada penelitian ini yaitu penanaman kedelai varietas Anjasmoro, karena memiliki rata-rata tinggi tanaman $42,83 \mathrm{~cm}$, jumlah daun 25,04 lembar, umur berbunga 43,62 hari, jumlah polong 13,00 buah, jumlah biji terbanyak sebesar 20,16 buah dan berat per 100 biji kedelai sebesar 12,78 g. Penggunaan pupuk kandang terbaik yaitu dengan menggunakan pupuk kandang kambing $400 \mathrm{~g}$ tiap polybag, karena mampu menghasilkan tanaman dengan tinggi rata-rata $48,11 \mathrm{~cm}$, jumlah daun 26,22 lembar, umur berbunga 43,16 hari, jumlah polong 13,89 buah, jumlah biji terbanyak sebesar 17,66 tiap polybag dan berat per 100 biji kedelai sebesar $12,56 \mathrm{~g}$.
\end{abstract}

Kata kunci : kedelai, varietas, pupuk kandang 


\section{PENDAHULUAN}

Kedelai merupakan salah satu jenis polong-polongan yang biasa digunakan sebagai bahan dalam pembuatan produk pangan seperti susu, kecap, tempe, tahu serta digunakan sebagai sayuran. Saat ini kebutuhan kedelai khususnya di Indonesia terus meningkat, ini dibuktikan dengan import kedelai mengalami peningkatan ratarata $0,5 \%$ per tahun (Abdillah, 2005), hal ini mendorong para petani maupun pemerintah di Indonesia memperluas lahan untuk menanam kedelai guna menurunkan jumlah import kedelai.

Varietas merupakan salah satu faktor yang turut menentukan produksi dan mutu benih yang dihasilkan (Putra, dkk, 2016). Kedelai memiliki beberapa varietas diantaranya varietas Wilis, varietas Anjasmoro, dan varietas Grobogan. Salah satu hal yang sangat berpengaruh untuk meningkatkan produksi kedelai yaitu unsur hara. Upaya yang dapat dilakukan yaitu dengan melakukan pemupukan. Pemupukan adalah pemberian pupuk dengan menambah persediaan unsur hara yang dibutuhkan oleh tanaman (Samekto, 2006). Pemupukan dapat dilakukan dengan menggunakan pupuk kandang.

Pupuk kandang merupakan pupuk yang berasal dari kotoran ternak baik berupa urin maupun feses serta sisa pakan yang tidak dimakan oleh ternak. Jenis pupuk kandang yang biasa dimanfaatkan yaitu pupuk kandang sapi, pupuk kandang ayam dan pupuk kandang kambing. Pupuk kandang sapi memiliki kandungan unsur $\mathrm{N}$, $\mathrm{P}$, $\mathrm{K}$ yang lebih tinggi. Unsur hara yang terkandung dalam pupuk kandang sapi yaitu $\mathrm{N} 2,33 \%, \mathrm{P}_{2} 0_{5} \quad 0,61 \%, \mathrm{~K}_{2} \mathrm{O} 1,58 \%, \mathrm{Ca}$ 1,04\%, Mg 0,33\%, Mn 179 ppm dan Zn 7,05 ppm, Pupuk kandang ayam merupakan pupuk kandang yang tegolong pupuk panas, pupuk kandang ayam relatif mudah terdekomposisi. Unsur hara yang terkandung dalam pupuk kandang ayam yakni N 3,21\%, $\mathrm{P}_{2} 0_{5} 3,21 \%, \mathrm{~K}_{2} \mathrm{O} 1,57 \%$, Ca $1,57 \%, \mathrm{Mg}$ 1,44\%, Mn $250 \mathrm{ppm}$ dan Zn $315 \mathrm{ppm}$ (Wiryanta dan Bernadinus, 2002). Pupuk kandang kambing merupakan pupuk kandang yang tergolong pupuk panas. Pupuk kandang kambing memiliki $\mathrm{C} / \mathrm{N}$ lebih dari 30. Unsur hara yang terkandung dalam pupuk kandang kambing yakni $\mathrm{N} 2,10 \%$, $\mathrm{P}_{2} \mathrm{O}_{5} 2,30 \%, \mathrm{~K}_{2} \mathrm{O} 1,97 \%, \mathrm{Ca} 2,00 \%, \mathrm{Mg}$ 0,60\%, Mn 233 ppm dan Zn 90,8 ppm (Samekto, 2006). Penelitian ini bertujuan untuk membuat kajian pengaruh penggunaan pupuk kandang terhadap pertumbuhan dan hasil tanaman kedelai pada tiga varietas kedelai.

\section{METODE PENELITIAN}

Penelitian lapangan dimulai dari tanam sampai panen dilaksanaan pada 29 September 2018 - 3 Januari 2019, bertempat di Desa Hargosari, Kecamatan Sine, Kabupaten Ngawi. Benih kedelai ditanam dalam polybag ukuran $15 \times 30 \mathrm{~cm}$ sebanyak 36 polybag, masing-masing berisi $4 \mathrm{~kg}$ tanah dan pupuk kandang sebanyak $400 \mathrm{~g}$. Perawatan tanaman kedelai meliputi penyiraman, pemupukan, serta pengendalian hama dan gulma. Penyiraman dilakukan setiap tiga hari sekali pada pagi hari. Pemupukan dilakukan tiga minggu setelah tanam yaitu dengan pupuk urea, $\mathrm{KCl}$ dan TSP. Pengamatan pada penelitian ini meliputi: tinggi tanaman, jumlah daun, umur berbunga, jumlah polong, jumlah biji, dan berat 100 biji kedelai. Data dianalisis menggunakan analisis ragam (ANOVA) dan dilanjutkan dengan uji Duncan (DMRT).

\section{HASIL DAN PEMBAHASAN Tinggi Tanaman Kedelai}

Data dan analisis ragam menunjukkan bahwa perlakuan baik varietas kedelai $(\mathrm{V})$, penggunaan pupuk kandang $(\mathrm{K})$ maupun interaksi antara varietas dan pupuk kandang (VK) tidak memberikan pengaruh yang nyata terhadap tinggi tanaman kedelai. Rata-rata tinggi tanaman tiga varietas kedelai dan pengaruh macam-macam pupuk kandang terdapat pada Tabel 1.

Data pengamatan menunjukkan bahwa varietas Wilis memiliki rata-rata tertinggi yaitu 45,50 $\mathrm{cm}$ dibanding dengan varietas lain dimana varietas Anjasmoro memiliki tinggi rata-rata $42,83 \mathrm{~cm}$ dan varietas Grobogan 38,50 cm. Hasil penanaman kedelai dipengaruhi oleh beberapa faktor yaitu faktor genetik dan faktor lingkungan. Jumin (2005), menyatakan bahwa selain faktor lingkungan, pertumbuhan tanaman juga dipengaruhi oleh faktor yang ada pada 
tanaman itu sendiri. Penelitian di Desa Hargosari, Kecamatan. Sine, Kabupaten. Ngawi memiliki rata-rata tinggi tanaman yang lebih rendah dibanding dengan penelitian yang dilakukan oleh Sumarmi (2018), yang menyatakan bahwa tinggi tanaman kedelai varietas Wilis $47-50 \mathrm{~cm}$, varietas Anjasmoro mencapai $60-65 \mathrm{~cm}$,

Tabel 1. Rata-rata tinggi tanaman tiga varietas kedelai dan pengaruh macam-macam pupuk kandang

\begin{tabular}{lc}
\hline \multicolumn{1}{c}{ Perlakuan } & Rata-rata tinggi tanaman $(\mathrm{cm})$ \\
\hline V1 = Wilis & $45,00^{\mathrm{a}}$ \\
V2 = Anjasmoro & $42,83^{\mathrm{a}}$ \\
V3 = Grobogan & $38,50^{\mathrm{a}}$ \\
K0 = Tanah & $40,33^{\mathrm{a}}$ \\
K1 = Tanah + Pupuk kandang sapi & $37,55^{\mathrm{a}}$ \\
K2 = Tanah + Pupuk kandang ayam & $42,44^{\mathrm{a}}$ \\
K3= Tanah + Pupuk kandang kambing & $48,11^{\mathrm{a}}$ \\
\hline
\end{tabular}

Berdasarkan Tabel 1, menunjukkan bahwa penggunaan pupuk kandang ayam menghasilkan tinggi tanaman lebih tinggi dibanding dengan penggunaan pupuk yang lainnya. Hal ini diduga pupuk kandang ayam memiliki kandungan fosfor $(\mathrm{P})$ yang lebih tinggi dibanding pupuk kandang lainnya sehingga dapat mempercepat pertumbuhan kedelai. Hamzah (2014), menyatakan bahwa pemberian pupuk kandang ayam pada tanaman kedelai dapat meningkatkan pertumbuhan kedelai yang meliputi tinggi tanaman, jumlah cabang, serta umur panen tanaman peningkatan pertumbuhan tanaman kedelai akibat pemberian pupuk kandang ayam yang mengandung unsur seperti Fosfor (P).

\section{Jumlah Daun Kedelai}

Hasil pengamatan dan analisis ragam menunjukkan bahwa perlakuan baik varietas (V) maupun penggunaan pupuk kandang (K) serta interaksi varietas dan pupuk kandang (VK) tidak memberikan pengaruh yang nyata terhadap jumlah daun sedangkan varietas Grobogan 50-60 cm. Hasil kedelai yang ditanam di Desa Hargosari, Kecamatan Sine, Kabupaten Ngawi ini tidak dapat menghasilkan tinggi tanaman yang optimum karena waktu penanaman kedelai yang tidak tepat sehingga pertumbuhan kedelai terhambat. pada tanaman kedelai. Rata-rata jumlah daun tiga varietas dan pengaruh macammacam pupuk kandang terdapat pada Tabel 2.

Berdasarkan Tabel 2, rata-rata jumlah daun varietas Grobogan (V3) merupakan jumlah daun paling sedikit yaitu 24,75 lembar. Rata-rata jumlah daun paling banyak yaitu pada varietas Wilis (V1) sebanyak 25,95 lembar diikuti varietas Anjasmoro (V2) sebanyak 25,04 lembar. Hasil penelitian tidak menunjukkan perbedaan yang nyata diduga waktu penanaman yang tidak tepat sehingga faktor lingkungan seperti lama penyinaran, suhu, dan kelembaban mempengaruhi proses terbentuknya daun. Faktor lingkungan yang sesuai untuk tanaman kedelai yaitu curah hujan 100-200mm/bulan, $\mathrm{pH}$ tanah 6,0-6,5, suhu harian $21-34^{\circ} \mathrm{C}$, kelembaban relatif 60 $70 \%$, naungan kurang dari $30 \%$, dan ketinggian lokasi penanaman 300-500 m dpl (Thuzar, et al, 2010).

Tabel 2.Rata-rata jumlah daun tiga varietas kedelai dan pengaruh macam-macam pupuk kandang

\begin{tabular}{lc}
\hline \multicolumn{1}{c}{ Perlakuan } & Jumlah daun (lembar) \\
\hline V1 = Wilis & $25,95^{\mathrm{a}}$ \\
V2 = Anjasmoro & $25,04^{\mathrm{a}}$ \\
V3 = Grobogan & $24,75^{\mathrm{a}}$ \\
K0 = Tanah & $24,22^{\mathrm{a}}$ \\
K1= Tanah + Pupuk kandang sapi & $26,11^{\mathrm{a}}$ \\
K2 = Tanah + Pupuk kandang ayam & $24,44^{\mathrm{a}}$ \\
K3= Tanah + Pupuk kandang & $26,22^{\mathrm{a}}$ \\
\hline
\end{tabular}


kambing

Rata-rata jumlah daun paling banyak yaitu dengan menggunakan pupuk kandang kambing (K3) yaitu 26,22 lembar dan jumlah daun yang paling sedikit yaitu tanpa penggunaan pupuk kandang (K0). Rata-rata jumlah daun penggunaan pupuk kandang sapi dan pupuk kandang ayam masingmasing 26,11 lembar dan 24,44 lembar. kandang kambing memiliki jumlah daun yang lebih banyak dibanding dengan penggunaan pupuk kandang yang lainnya.

Hal ini diduga pupuk kandang kambing menyediakan unsur hara yang cukup dalam proses pembentukan daun tanaman kedelai yang diduga diakibatkan adanya unsur $\mathrm{P}$ didalam pupuk kandang kambing. Faizin, dkk (2015), menyatakan bahwa pertumbuhan tanaman yang baik dapat tercapai apabila faktor lingkungan yang mempengaruhi pertumbuhan dapat berimbang dan menguntungkan. Fosfor dibutuhkan untuk merangsang penyerapan unsur hara melalui peningkatan jumlah bintil pada perakaran sehingga dapat
meningkatkan pertumbuhan tanaman.

\section{Umur Berbunga Kedelai}

Data dan analisis ragam menunjukkan bahwa perlakuan baik varietas (V), pupuk kandang (K), dan interaksi varietas dan pupuk kandang (VK) tidak memberikan pengaruh yang nyata terhadap umur berbunga kedelai. Rata-rata umur berbunga tiga varietas kedelai dan pengaruh macam-macam pupuk kandang terdapat pada Tabel 3.

Rata-rata umur berbunga pada masing-masing varietas kedelai menunjukkan bahwa varietas Grobogan (V1) memiliki umur bebunga tercepat yaitu 43,41 hari dibanding dengan varietas lain. Varietas Wilis (V1) memiliki rata-rata umur berbunga 43,83 dan varietas Anjasmoro (V2) 43,62 hari. Sumarmi (2018) menyatakan bahwa umur berbunga pada varietas Wilis berkisar 38-40 hari, varietas Anjasmoro berkisar 36-39 hari, sedangkan varietas Grobogan berkisar 30-32 hari.

Tabel 3. Rata-rata umur berbunga tiga varietas kedelai dan pengaruh macam-macam pupuk kandang

\begin{tabular}{lc}
\hline \multicolumn{1}{c}{ Perlakuan } & Umur berbunga (hari) \\
\hline V1 = Wilis & $43,83^{\mathrm{a}}$ \\
V2 = Anjasmoro & $43,62^{\mathrm{a}}$ \\
V3 = Grobogan & $43,41^{\mathrm{a}}$ \\
K0 = Tanah & $43,44^{\mathrm{a}}$ \\
K1= Tanah + Pupuk kandang sapi & $43,94^{\mathrm{a}}$ \\
K2 = Tanah + Pupuk kandang ayam & $43,94^{\mathrm{a}}$ \\
K3 = Tanah + Pupuk kandang & $43,16^{\mathrm{a}}$ \\
kambing & \\
\hline
\end{tabular}

Hasil penelitian kedelai yang dilakukan di Desa Hargosari, Kecamatan Sine, Kabupaten Ngawi menunjukkan ratarata umur berbunga pada masing-masing varietas lebih lambat karena penanaman dilakukan sudah memasuki musim hujan sehingga lama penyinaran pada tanaman kedelai kurang optimal, hal ini menyebabkan umur berbunga kedelai lebih lama. Riawati, dkk (2016), menyatakan bahwa perbedaan umur tanaman berbunga antar variteas dipengaruhi oleh sifat genetik pada masing-masing varietas. Faktor utama dalam pembungaan pada tanaman kedelai lebih dominan dipengaruhi oleh sifat genetik tanaman.

Rata-rata umur berbunga tanaman kedelai tercepat yaitu dengan penggunaan pupuk kandang kambing. Penggunaan pupuk kandang kambing (K3) rata-rata 43,16 hari tanaman kedelai sudah mulai berbunga. Penggunaan pupuk kandang sapi (K1) dan pupuk kandang ayam (K1) memiliki ratarata umur berbunga yang sama yaitu pada 43,94 hari. Kedelai tanpa penggunaan pupuk kandang (K0) memiliki rata-rata umur berbunga 43,44 hari. Diduga pupuk kandang kambing memiliki unsur $\mathrm{P}$ yang lebih sehingga dapat mempercepat umur berbunga 
tanaman kedelai. Tanaman banyak memerlukan zat makanan seperti unsur hara nitrogen dan fosfor yang dibutuhkan pada saat pembungaan. Pada saat pembentukan kuncup-kuncup bunga, tanaman banyak menyerap unsur hara nitrogen dan fosfor yang dapat mempercepat pembungaan (Sutejo, 2005).

\section{Jumlah Polong Kedelai}

Hasil analisis ragam menunjukkan bahwa perlakuan baik varietas (V) maupun penggunaan pupuk kandang (K) serta interaksi varietas dan pupuk kandang (VK) tidak memberikan pengaruh yang nyata terhadap jumlah polong kedelai. Rata-rata Jumlah polong tiga varietas kedelai dan pengaruh macam-macam pupuk kandang terdapat pada Tabel 4.

Rata-rata jumlah polong pada Tabel 4 menunjukkan bahwa varietas Wilis (V1) memiliki jumlah polong terbanyak yaitu 14,33 pada tiap tanaman kedelai. Varietas
Anjasmoro (V2) dan varietas Grobogan memiliki jumlah polong yang sama yaitu sebanyak 13,00 tiap tanaman kedelai. Ratarata jumlah polong tertinggi sebesar 14,67 buah yaitu dengan penggunaan pupuk kandang sapi (K1) dan terendah tanpa menggunakan pupuk kandang (K0) yaitu sebesar 11,89 buah. Penggunaan pupuk kandang ayam (K2) memiliki jumlah polong rata-rata 13,33 buah setiap tanaman kedelai dan pupuk kandang kambing (K3) sebesar 13,89 buah. Hal ini diduga masing-masing varietas memiliki sifat genetik yang berbeda. Selain hal tersebut diduga varietas Wilis mampu beradaptasi dengan baik terhadap kondisi lingkungan sehingga dapat mempengaruhi dalam proses terbentuknya polong. Pembentukan dan pengisian polong sangat ditentukan oleh genetik tanaman yang berhubungan dengan kemampuan sumber asimilat dan tempat penumpukan pada tanaman (Riawati, dkk, 2016).

Tabel 4. Rata-rata jumlah polong tiga varietas kedelai dan pengaruh macam-macam pupuk kandang

\begin{tabular}{lc}
\hline \multicolumn{1}{c}{ Perlakuan } & Jumlah polong (buah) \\
\hline V1 = Wilis & $14,33^{\mathrm{a}}$ \\
$\mathrm{V} 2=$ Anjasmoro & $13,00^{\mathrm{a}}$ \\
$\mathrm{V} 3=$ Grobogan & $13,00^{\mathrm{a}}$ \\
$\mathrm{K} 0=$ Tanah & $11,89^{\mathrm{a}}$ \\
$\mathrm{K} 1=$ Tanah + Pupuk kandang sapi & $14,67^{\mathrm{a}}$ \\
$\mathrm{K} 2=$ Tanah + Pupuk kandang ayam & $13,33^{\mathrm{a}}$ \\
$\mathrm{K} 3=$ Tanah + Pupuk kandang & $13,89^{\mathrm{a}}$ \\
kambing & \\
\hline
\end{tabular}

\section{Jumlah Biji Kedelai}

Data dan analisis ragam menunjukkan bahwa perlakuan baik varietas (V) maupun pupuk kandang (K) tidak memberikan pengaruh yang nyata, namun interaksi antara varietas dan pupuk kandang (VK) memberikan pengaruh yang nyata terhadap jumlah biji kedelai. Rata-rata jumlah biji tiga varietas kedelai dan

pengaruh macam-macam pupuk kandang terdapat pada Tabel 5.

Tabel 5. Rata-rata jumlah biji tiga varietas kedelai dan pengaruh macam-macam pupuk kandang

\begin{tabular}{lc}
\hline \multicolumn{1}{c}{ Perlakuan } & Jumlah biji \\
\hline V1 = Wilis & $18,50^{\mathrm{a}}$ \\
V2 = Anjasmoro & $20,16^{\mathrm{ab}}$ \\
V3 = Grobogan & $15,41^{\mathrm{a}}$ \\
K0 = Tanah & $16,33^{\mathrm{a}}$ \\
K1 = Tanah + Pupuk kandang sapi & $18,66^{\mathrm{a}}$ \\
K2 = Tanah + Pupuk kandang ayam & $19,44^{\mathrm{ab}}$ \\
\hline
\end{tabular}




\begin{tabular}{|c|c|}
\hline $\begin{array}{l}\text { K3= Tanah + Pupuk kandang } \\
\text { kambing }\end{array}$ & $17,66^{\mathrm{a}}$ \\
\hline $\begin{array}{l}\text { Berdasarkan Tabel } 5 \text { varietas } \\
\text { Anjasmoro (V2) memiliki rata-rata jumlah } \\
\text { biji terbanyak yaitu sebesar 20,16 jika } \\
\text { dibandingkan dengan varietas lainnya } \\
\text { dimana masing-masing varietas yaitu } \\
\text { varietas Wilis (V1) yang memiliki rata-rata } \\
\text { jumlah biji sebesar 18,50 dan varietas } \\
\text { Grobogan (V3) yang memiliki rata-rata } \\
\text { jumlah biji sebesar 15,41. Hal ini diduga } \\
\text { faktor genetik menyebabkan terjadinya } \\
\text { perbedaan produktivitas tanaman kedelai. } \\
\text { Menurut Soverda dan Hermawati (2009), } \\
\text { menyatakan bahwa hasil dari suatu tanaman } \\
\text { ditentukan oleh faktor genetik yang meliputi } \\
\text { ketahanan terhadap hama dan patogen, serta } \\
\text { kekeringan dan sifat tanaman hibrid. Faktor } \\
\text { lingkungan meliputi suhu, ketersediaan air, } \\
\text { cahaya matahari, struktur dan komposisi } \\
\text { tanah, reaksi tanah serta mikroorganisme. } \\
\text { Varietas Anjasmoro memiliki produktivitas } \\
\text { yang tinggi, memiliki biji yang besar, dan } \\
\text { polong yang tidak mudah pecah (Jumakir } \\
\text { dan Endrizal, 2003). }\end{array}$ & $\begin{array}{l}\text { Berdasarkan uji Duncan pada Tabel } \\
\text { 5, penggunaan pupuk kandang ayam (K2) } \\
\text { memiliki rata-rata jumlah biji terbanyak } \\
\text { yaitu sebesar 19,44. Rata-rata jumlah biji } \\
\text { terndah yaitu pada perlakuan tanpa } \\
\text { menggunakan pupuk kandang (K0) yaitu } \\
\text { sebesar 16,33. Penggunaan pupuk kandang } \\
\text { sapi (K1) dan pupuk kandang kambing (K3) } \\
\text { memiliki rata-rata masing-masing 18,66 dan } \\
\text { 17,66. Hal ini diduga pupuk kandang ayam } \\
\text { memiliki kandungan fosfor (P) yang lebih } \\
\text { tinggi dibanding pupuk kandang lainnya } \\
\text { sehingga dapat mempercepat pertumbuhan } \\
\text { kedelai. Hal ini sesuai dengan pendapat } \\
\text { Musnamar (2003), yang menyatakan bahwa } \\
\text { pupuk kandang ayam mengandung unsur } \\
\text { Nitrogen } 1,40 \% \text {, Fosfor } 0,80 \% \text { - } 1,00 \% \text { dan } \\
\text { Kalium } 0,40 \% \text { serta berbagai hara mikro. } \\
\text { Berat } 100 \text { Biji Kedelai } \\
\text { Rata-rata berat } 100 \text { biji tiga varietas } \\
\text { kedelai dan pengaruh macam-macam pupuk } \\
\text { kandang terdapat pada Tabel } 6 \text {. }\end{array}$ \\
\hline $\begin{array}{l}\text { Tabel 6. Rata-rata berat } 100 \text { biji tiga varietas } \\
\text { kandang }\end{array}$ & kedelai dan pengaruh macam \\
\hline Perlakuan & Berat 100 biji kedelai $(\mathrm{g})$ \\
\hline $\begin{array}{l}\text { V1 }=\text { Wilis } \\
\text { V2 = Anjasmoro } \\
\text { V3 = Grobogan } \\
\text { K0 = Tanah } \\
\text { K1= Tanah + Pupuk kandang sapi } \\
\text { K2 = Tanah }+ \text { Pupuk kandang ayam } \\
\text { K3 = Tanah + Pupuk kandang } \\
\text { kambing }\end{array}$ & $\begin{array}{c}9,92 \\
12,78 \\
11,61 \\
11,65 \\
9,74 \\
11,80 \\
12,56\end{array}$ \\
\hline
\end{tabular}

Rata-rata berat 100 biji kedelai tertinggi yaitu pada varietas Anjasmoro dengan berat rata-rata yaitu $12,78 \mathrm{~g}$. ratarata berat varietas Wilis dan varietas Grobogan masing-masing 9,92 g dan 11,61 g. Hasil penelitian ini lebih rendah dibanding penelitian yang dilakukan oleh Sumarmi (2018), yang memiliki rata-rata berat 100 biji kedelai varietas Wilis 10,0 10,2 g, varietas Anjasmoro 14,8-15,3 g, varietas Grobogan 17,8-18,2 g. Rendahnya berat masing-masing varietas kedelai diduga faktor cuaca yang kurang mendukung pada saat pembentukan biji seperti cahaya matahari, kelembaban, dan suhu. Menurut Soverda dan Hermawati
(2009), menyatakan bahwa hasil dari suatu tanaman ditentukan oleh faktor genetik yang meliputi ketahanan terhadap hama dan patogen, serta kekeringan dan sifat tanaman hibrid. Faktor lingkungan meliputi suhu, ketersediaan air, cahaya matahari, struktur dan komposisi tanah, reaksi tanah serta mikroorganisme. Varietas Anjasmoro memiliki produktivitas yang tinggi, memiliki biji yang besar, dan polong yang tidak mudah pecah (Jumakir dan Endrizal, 2003).

Penanaman kedelai dengan menggunakan pupuk kandang kambing menghasilkan berat tertinggi yaitu $12,56 \mathrm{~g}$. Penanaman kedelai dengan penambahan 
pupuk kandang sapi menghasilkan berat terendah yaitu $11,65 \mathrm{~g}$. Rata-rata berat 100 biji kedelai dengan tanpa penambahan pupuk kandang dan pupuk kandang ayam masing-masing $11,65 \mathrm{~g}$ dan $11,80 \mathrm{~g}$. Hal ini diduga pupuk kandang kambing menyediakan unsur hara yang cukup dalam proses pematangan biji kedelai yang diduga diakibatkan adanya unsur $\mathrm{P}$ di dalam pupuk kandang kambing. Hal ini sesuai dengan pernyataan Sutejo (2002), yang menyatakan unsur $\mathrm{P}$ berperan dalam meningkatkan pengisisan biji tanaman kedelai sehingga dengan pemberian $\mathrm{P}$ yang tinggi akan meningkatkan berat biji kedelai.

\section{KESIMPULAN}

Berdasarkan hasil penelitian dapat disimpulkan bahwa varietas dan pupuk kandang tidak memberikan pengaruh terhadap pertumbuhan dan hasil tanaman kedelai. Namun terjadi interaksi antara varietas dan pupuk kandang dalam menghasilkan jumlah biji kedelai. Data penelitian menunjukkan bahwa perlakuan terbaik pada penelitian ini yaitu varietas Anjasmoro dengan penggunaan pupuk kandang kambing. Varietas Anjasmoro memiliki rata-rata tinggi tanaman $42,83 \mathrm{~cm}$, jumlah daun 25,04 lembar, umur berbunga 43,62 hari, jumlah polong tiap polybag 13,00 , jumlah biji 20,16 tiap polybag, dan berat tiap 100 biji kedelai 12,78 g. Penanaman kedelai dengan penggunaan pupuk kandang kambing memiliki rata-rata tinggi tanaman $48,11 \mathrm{~cm}$, jumlah daun 26,22 lembar, umur berbunga 43,16 hari, jumlah polong tiap polybag 13,89, jumlah biji 17,66 tiap polybag dan berat tiap 100 biji kedelai 12,56 g.

\section{DAFTAR PUSTAKA}

Abdillah,Rizma. 2005. Proyeksi Produksi dan Konsumsi Kedelai Indonesia.JEKT. 8(1) : 9-13.

Faizin, N., Mardiansyah, M dan Yoza, D. 2015. Respon Pemberian Beberapa Dosis Pupuk Fosfor Terhadap Pertumbuhan Semai Akasia (Acacia mangium Willd.) dan Kesediaan fosfor di tanah. JOM Faperta. 2(2) : $1-9$.
Hamzah, Suryawaty.2014. Pupuk Organik Cair dan Pupuk Kandang Ayam Berpengaruh Kepada Pertumbuhan dan Produksi Kedelai (Glycine max L.). J. Agrium. 3(18) : 228-234.

Jumakir dan Endrizal.2014. Produktivitas Kedelai Varietas Anjasmoro Pada Kondisi Cekaman Kekeringan di Provinsi Jambi.Prosiding Seminar Hasil Penelitian Tanaman Aneka Kacang dan Umbi. Balai Pengkajian Teknologi Pertanian Jambi : 282287.

Jumin.H.B. $2005 . \quad$ DasardasarAgronomi.Raja Grafindo Perseda. Jakarta. 264 hal.

Putra, R.R., Syafruddin dan Jumini. 2016. Produksi dan Mutu Benih Beberapa Varietas Kedelai Lokal Aceh (Glycine $\max$ (L.) merr.) Dengan Pemberian Dosis Mikoriza Yang Berbeda Pada Tanah Entisol. J.Kawista. 1(1) : 37-44.

Riawati.,Rasyad, A dan Wardati. 2016. Respon Empat Varietas Kedelai (Glycine max (L). Merril) Terhadap Pemberian Beberapa Dosis Pupuk Fosfor.JOM Faperta. 3(1) : 1-12.

Samekto, R. 2006. Pupuk Kandang. PT.Citra Aji Parama.Yogyakarta.

Soverda, N dan Hermawati, T. 2009. Respon Tanaman Kedelai (Glycine max L.Merill) Terhadap Pemberian Berbagai Konsentrasi Pupuk Hayati.J.Agronomi. 13 (1).

Sumarmi. 2018. Seleksi Kultivar Kedelai : Persiapan Pemuliaan Tanaman Dengan Metode Kultur Mikrospora. J. AGRIC. 30(2) : 125-133.

Sutejo. 2002. Pupuk dan Cara Pemupukan. PT. Rineka Cipta. Jakarta.17 hal.

Sutejo. 2005. Pupuk dan Cara Pemupukan. PT. Rineka Cipta. Jakarta. Cetakan kedelapan.

Thuzar, M., Puteh, A.B., Abdullah, N.A.P., Mohd.Lassim, M.B and Jusoff, K. 2010. The Effect of Temperature Stress On The Quality and Yield Of Soyabean [(Glycine $\max \quad$ L.) 
ISSN (Print) : 1693-0738

Innofarm:Jurnal Inovasi Pertanian Vol. 21 (1), April 2019

Merill.]. Journal of Agricultural

Science. 2(1) : 172-179.
Wiryanta, W dan Bernardinus, T. 2002.

Bertanam Cabai Pada Musim Hujan. Agromedia Pustaka. Jakarta. 